\title{
Urgences
}

\section{Incognito ergo sum}

\section{Hugues Nault}

Numéro 20, mai 1988

\section{Appellation contrôlée}

URI : https://id.erudit.org/iderudit/025473ar

DOI : https://doi.org/10.7202/025473ar

Aller au sommaire du numéro

\section{Éditeur(s)}

Urgences

\section{ISSN}

0226-9554 (imprimé)

1927-3924 (numérique)

Découvrir la revue

Citer ce document

Nault, H. (1988). Incognito ergo sum. Urgences, (20), 28-29.

https://doi.org/10.7202/025473ar

Ce document est protégé par la loi sur le droit d'auteur. L'utilisation des services d'Érudit (y compris la reproduction) est assujettie à sa politique d'utilisation que vous pouvez consulter en ligne.

https://apropos.erudit.org/fr/usagers/politique-dutilisation/
Cet article est diffusé et préservé par Érudit.

Érudit est un consortium interuniversitaire sans but lucratif composé de l'Université de Montréal, l'Université Laval et l'Université du Québec à Montréal. Il a pour mission la promotion et la valorisation de la recherche. https://www.erudit.org/fr/ 


\section{HUGUES NAULT \\ Incognito ergo sum}

Nîmes, mars 1988

$\mathrm{Mme} / \mathrm{M}$. la/le directrice/directeur du/de la revue/ urgent/e,

Je vous remercie d'avoir fait appel (anonyme) à mes services pour votre numéro spécial anonyme. Vous ne serez pas déç(h)u, car je suis affectivement un(e) aut(eu)re tout ce qu'il y a de plus anonyme puisque je n'ai publié, jusqu'à présent, que sous divers pseudonymes. Et grâce à cette occasion inespérée (ininspirée?) que vous m'offrez, je pourrai le demeurer, car on ne croira voir, ici encore, qu'un(e) autre pseudonyme.

Voici donc les vers pros(arch)aïques - Vous êtes bien une revue de Poésie, n'est-ce-pas? -, de circon-stances et sans prétention, que j'ai commis, voyageur, pour l'occazion, qui, selon la Sagesse des Notions, fait le «lirons»:

Anonymot(s): échec et anonymat

Alibi bi(bli)o d'anonymat s'honore

Un connu et inconnus l'un (en) l'autre se métaphorent pareils à ceux qui déjà, hélas, sont trop tôt oxymorts

Parmi les stratégies pour la célé(b)rité, voilà certes le masque le plus dé(b)ridé.

Pourtant, il nous oblige à une ouverte lecture-moins préjugée, au point qu'il faudrait, selon nous, son usage généraliser

En effet, en bien des lieux ne voit-on pas le $\mathrm{Pa}(\mathrm{t})$ ronyme ét(r)e/i/ndre (de) son ombre illimitée(sur) le texte, qu'il domine. Mais voilà - soyons francs - : sans lui plus rien ne nous anyme et nous nous voyons disparêtre au tréfonds de l'abîme.

Anonymat! sous ton couvert, nous voulons bien retomber en toi mais pour en sortir au plus vite, car l'Ego, lui, est roi

Et le cache-cache ne nous charme que si une trace(s'é)cri.: c'est moi!

Excusez-la! 
Merci de votre attention,

Incognito ergo sum «bien à vous»,

Hugues NAULT 